\title{
Mortality and incidence of cancer among a cohort of self employed butchers from Geneva and their wives
}

\author{
E Gubéran, M Usel, L Raymond, G Fioretta
}

\begin{abstract}
To investigate whether specific cancers are associated with the occupation of butcher, as has been reported from other countries, a historical prospective cohort study was undertaken. The cohort consisted of all self employed butchers $(n=552)$ and pork butchers $(n=310)$ born since 1880 who set up a shop in the canton of Geneva from 1901 to 1969 , and of their wives $(n=887)$. The study group was followed up from 1901 to 1990 for general mortality, from 1942 to 1990 for cause specific mortality, and from 1970 to 1989 for incidence of cancer. There was no trace of $\mathbf{4 5}$ men $(5 \%)$ and 52 women (6\%). Compared with the general population of the canton of Geneva, butchers and pork butchers experienced a significant increase, taking into account 15 years of latency, in mortality from all causes (observed deaths (Obs) 540, expected deaths (Exp) 445.5, standardised mortality ratio (SMR) 121, 90\% confidence interval $(90 \% \mathrm{Cl})$ 113-130). There were significant excesses in incidence and mortality from colorectal cancer, cancer of the prostate, and all malignant neoplasms, and in incidence of cancer of the liver. The risk of lung cancer was significantly increased among pork butchers (SMR 176, 90\% Cl 114-262; standardised incidence ratio (SIR) $231,90 \% \mathrm{Cl} 137-368$ ) but not among butchers (SMR 92, 90\% Cl 59-138; SIR $113,90 \% \mathrm{Cl}$ 67-179). There was also a significant increase in mortality from cancer of the larynx among butchers. For non-malignant causes of death significant excesses were found among all men for ischaemic heart disease, motor vehicle accidents, and cirrhosis of
\end{abstract}

Geneva Medical Inspectorate of Factories, CH-1207 Geneva

E Gubéran, M Usel

Geneva Cancer registry, CH 1205 Geneva

Switzerland

L Raymond, G Fioretta the liver. Analysis of subgroups showed a cluster of deaths from leukaemia among older butchers born between 1880 and 1899 (Obs 5, $\operatorname{Exp} 0.6, p<0.001)$. Exposure of pork butchers to polycyclic aromatic hydrocarbons during meat smoking, which was assessed in a contemporary study, might have contributed to their increased risk of lung cancer. The possible role of other factors, especially cigarette smoking, nitrosamines, and oncogenic viruses was discussed. Moreover, there was evidence from another contemporary study that butchers and pork butchers ate more animal fat, and probably more animal protein, than the average male population of Geneva. These results suggest that dietary factors could be implicated in the excesses of colorectal cancer, cancer of the prostate, and ischaemic heart disease. An increased risk for alcohol abuse might explain the excesses of liver cirrhosis, cancer of the liver, cancer of the larynx, and motor vehicle accidents. Among all wives overall mortality was similar to that expected (SMR 100, 90\% Cl 93-108) and there was no significant excess risk for any specific cancer nor for any non-malignant cause of death. Results for cancer of the cervix uteri, especially among subgroups, suggest an increased risk consistent with previous findings from other countries.

(British Fournal of Industrial Medicine 1993;50:1008-1016)

Studies from several countries on butchers and other meat workers have shown excess risks for several malignancies especially for lung cancer, prostatic cancer, leukaemia, and lymphoma. ${ }^{1-8}$ Various hypotheses have been considered to explain the excess cancers although adequate evidence of the causal role of occupational factors was not produced. The aim of the present study was to investigate mortality and incidence of cancers among a cohort of Geneva butchers and pork butchers, and their wives. 
Table 1 Numbers of butchers and pork butchers by year of setting up shop in the canton of Geneva (excluding those born before 1880)

\begin{tabular}{lccc}
\hline Year of setting up & Butchers & Pork butchers & Total \\
\hline $1901-09$ & 18 & 12 & 30 \\
$1910-19$ & 47 & 35 & 82 \\
$1920-29$ & 123 & 87 & 210 \\
$1930-39$ & 120 & 91 & 211 \\
$1940-49$ & 60 & 45 & 105 \\
$1950-59$ & 106 & 28 & 134 \\
$1960-69$ & 78 & 12 & 90 \\
Total & $552^{\circ}$ & 310 & 862 \\
\hline
\end{tabular}

${ }^{\star}$ Including 38 butchers of horse meat.

\section{Population and methods}

DEFINITION OF THE COHORT AND FOLLOW UP

Butchers and pork butchers included in this study were self employed tradesmen who ran their own business with their wife only, or with a few employees. The occupations of butcher and pork butcher were in principle separated up to about 1950 , similar to the custom in France but contrary to that in the German speaking part of Switzerland. Pork butchers processed and sold only pork, whereas butchers sold fresh beef, veal, and mutton. Afterwards this separation tended to be less stringent and butchers started to sell pork meat products that they usually bought from wholesalers, although a few butchers started to process these products.

The basic cohort of men consisted of all butchers and all pork butchers born since 1880 who set up their own shop in the canton of Geneva up to 1969. Lists of self employed butchers and of pork butchers have been published annually since 1877 in a Geneva year book, the "Annuaire Genevois." The 1217 butchers and pork butchers whose names appeared on the lists between 1901 and 1969 were identified in the records of the population office of the canton of Geneva. The 283 men born before 1880 were excluded as well as 72 men not found in the records probably because of a wrong name, missing file, or residence in the neighbouring regions of Switzerland or of France. The remaining 862 constituted the study cohort of men.

Since the 1950s an increasing part of the market of meat, up to two thirds in recent years, has been taken by a few multiple butchers and by supermarkets. This explains why the number of butchers setting up shop was lower in the 1950s and 1960s than in the two decades before the second world war (table 1).

A total of 916 wives was identified in the Population Office records or in the "Families' Register" of the commune of origin of the 862 butchers and pork butchers. The 29 women who married after their husband had left the occupation of butcher, or who died or were divorced before the start of follow up of their husband, were eliminated. The remaining 887 women constituted the study cohort of wives.

Men were traced from 1 January of the first year they were registered in the Geneva year book. Wives were traced from the same date as their husband or from the date of their marriage if it took place later. With methods previously described in detail, ${ }^{9}$ butchers and their wives were traced by the records of the Geneva population office, by the Families' Register of their commune of origin, and by the population offices of other Swiss cities. Those who had reached the age of 65 for men and 62 for women were also traced by the Swiss old age pension scheme. Butchers and their wives were followed up to 31 December 1990 (208 men and 384 women alive), or to their death (609 men, 451 women), or to the date their trace was lost (45 men $(5 \cdot 2 \%), 52$ women $(5 \cdot 9 \%))$.

Usually butchers and pork butchers spend several years as apprentices and as employees before running their own shop. Some butchers moved to Geneva from others Swiss cantons or from other countries where they may have run a shop. At the beginning of follow up the mean age was 32.5 years for men and 31.0 years for women. The 862 men contributed 29330 person years of observation and the 887 wives 34041 person years.

\section{MORTALITY AND INCIDENCE OF CANCER}

Mortality from all causes was recorded for the whole study period (1901 to 1990) and cause specific mortality was analysed from 1942 to 1990 because death certificates in Switzerland have been kept only since 1942 by the Federal Office of Statistics. That office supplied us with the official coding of the cause of death for members of the cohort who died within the country, except for three men and one wife whose certificates could not be found.

For the 23 men and 23 wives who died in foreign countries, the cause of death was found from the death certificate for one wife and from the attending physician for another wife and two men. Also, information from a next of kin was considered sufficiently reliable for seven deaths among men of which the causes were myocardial infarction (International Classification of Diseases, 8th revision (ICD-8): code 410), ill defined heart disease (429), alcoholic cirrhosis of the liver (571.0), traffic accident (814), sudden death (795; two men), and violent death from uncertain cause (988). The causes of the remaining 14 deaths in men and 21 deaths in wives were not found. Expected deaths were calculated from sex, age, and year specific regional rates.

Incidence of cancer was analysed from 1 January 
1970, the starting date of the Geneva Cancer Registry, to 31 December 1989. All incident cancers, except in situ cancers, were collected by the Registry among the 454 men and the 586 wives who lived in the canton of Geneva in the years 1970 to 1989 . The periods of residence in other Swiss cantons had to be excluded for there is no national cancer registry. Expected cancer cases have been calculated from Geneva sex and age specific mean incidence rates for 1970-4, 1975-9, 1980-4, and 1985-9.

The usual statistical analysis based on the Poisson distribution was used to test the one sided significance of the excesses of observed deaths and incident cancers. Tests for homogeneity and for trend in the standardised mortality ratios (SMRs) and the standardised incidence ratios (SIRs) were made with the methods described by Breslow and Day. ${ }^{10}$

\section{HAZARDOUS EXPOSURES OF GENEVA BUTCHERS AND PORK BUTCHERS}

Studies have pointed to a risk of cancer among slaughterhouse workers involved in daily slaughter of cattle, sheep and pigs. ${ }^{3-5}$ In Geneva, during the first half of this century, most butchers and pork butchers used the slaughterhouse for slaughtering animals, but only for their own business requirements. On average a butcher killed about one head of cattle or less, one or two calves, and one or two sheep each week, and a pork butcher only two or three pigs. Since the building of the new Geneva slaughterhouse in 1949, the slaughtering and carcass dressing operations have been carried out by abattoir workers not included in the present study. Quarters of beef and mutton were kept refrigerated for one night and delivered the next day to the butcher's shop where the meat was cut, prepared, and sold. Pork, however, after evisceration and splitting, was delivered immediately to the pork butcher who was therefore still exposed to warm meat. Since 1975, veterinary authorities have decreed that the pork should be chilled before delivery. At the pork butcher's shop meat was cut, cured, smoked, and further processed, and pork meat products were sold.

Meat smoking was carried out almost daily in a smoking cupboard, generally about $1.5 \mathrm{~m} \times 1.5 \mathrm{~m}$ square and as high as the ceiling, situated within a room called the "laboratory" in the back of the shop where the pork butcher processed meat products. The cold smoke process (temperature less than $25^{\circ} \mathrm{C}$, duration about 12 hours) used smouldering sawdust from various woods, preferably hard woods. Once or twice a week, smoking of sausages such as wieners and salami necessitated the hot smoke process (temperature up to $70^{\circ} \mathrm{C}$, duration about two hours) with sawdust and chipped wood.
With the hot smoke process in particular the pork butcher had to often open the door of the smoking cupboard for loading, controlling, turning and finally unloading sausages and prepared meats.

In a contemporary study (Vu Duc $\mathrm{T}$, personal communication) the profile and concentrations of polycyclic aromatic hydrocarbons (PAHs) were determined in the "laboratories" of Geneva pork butchers during meat smoking with the two traditional methods. Preliminary results indicated that exposures to total PAHs were of the same order of magnitude as those found in 10 Danish smokehouses using the classical technique. ${ }^{11}$ Initial measurements of benzo[a]pyrene showed a concentration range from $0.05 \mu \mathrm{g} / \mathrm{m}^{3}$ to $0.4 \mu \mathrm{g} / \mathrm{m}^{3}$ for the cold smoke process, and a concentration of $1.3 \mu \mathrm{g} / \mathrm{m}^{3}$ for the hot smoke process. Various ingredients were used in meat curing and pickling including sodium chloride, potassium nitrate, sugar, citric acid, spices, and sodium nitrite. The last has been widely used only since the 1960 s by pork butchers to whom it was sold by the state in nitrited salt form (cooking salt with $0.6 \%$ of sodium nitrite). Certain curing mixtures have been shown to contain several nitrosamines ${ }^{12}$ to which exposure by inhalation and skin absorption, although limited, seems possible.

Normally only pork is cured and smoked. Therefore those who were exposed to PAHs from meat smoking, and possibly to nitrosamines from meat curing, were all pork butchers and the few butchers who processed pork meat products after 1950.

Preserved meat and fish are among the food items with the highest content of nitrosamines, which are formed from the nitrites and nitrates used in curing. ${ }^{12-14}$ Butchers and pork butchers are assumed to consume more meat than the average population and to eat the pieces of meat they cannot sell. Therefore, there is little doubt that the consumption of nitrosamines from pork was higher among pork butchers than among butchers, especially before 1950, and than among the general population.

Exposure to fumes from plastic used in wrapping machines that cut and seal plastic by heat has been suggested as a risk factor for malignancies in meat workers. ${ }^{1-4}$ Some Geneva butchers and pork butchers, estimated to be a few per cent in the 1970s and about $20 \%$ in the 1980 s, used such machines for vacuum wrapping, although for no more than 15 minutes a day. This wrapping was used to preserve pieces of meat for one or two weeks, but never for retail sales. It has been pointed out that there is little evidence of carcinogenicity in these fumes from plastic that can induce meat wrapper's asthma. ${ }^{6}$

According to the Geneva veterinary authorities, butchers from Geneva used only cooking salt for 
the treatment of pelts, by contrast with butchers from other countries such as New Zealand who used trichlorophenol, an agent suspected to induce lymphoma and soft tissue sarcoma in humans. ${ }^{7}$ Also, they did not use the antioxydants butylated hydroxyanisole (BHA) and butylated hydroxytoluene (BHT) that are carcinogenic in animals and were used in the meat industry of the United States. ${ }^{1-3}$

Wives played an important part in the sale to the customers but they never participated in the processing of meat products because most butchers and pork butchers believed that the presence of women, especially during their periods, could have harmful effects-for instance, making the pickling solution go bad.

\section{DIETARY HABITS OF GENEVA BUTCHERS}

In a contemporary study undertaken in 1989 by the Geneva Cancer Registry, ${ }^{15} 72$ butchers and 96 population controls were randomly selected. Among them 45 butchers and 43 controls agreed to be interviewed by a trained dietician with a dietary history questionnaire. The $\mathbf{4 5}$ men referred to as butchers were classified as 36 butchers and nine pork butchers.

Results indicated that the average daily caloric intake, adjusted for age, was higher among butchers $(2815 \mathrm{kcal})$ than among controls $(2527 \mathrm{kcal})$, although the difference was not significant. Overweight butchers (body mass index $>25$ ) were significantly more common than overweight controls. As expected, butchers consumed significantly more animal fat than controls after adjustment for caloric intake and age (respectively $24.8 \%$ and $19.5 \%$ of total caloric intake without alcohol). The intake of animal protein was also higher among butchers, although not significantly so. The proportion of current smokers was $50 \%$ among the 36 butchers, $33 \%$ among the nine pork butchers, and $35 \%$ among the 43 controls.

\section{Results}

BUTCHERS AND PORK BUTCHERS

For the total period of observation (1901 to 1990) overall mortality of all men was significantly higher than expected (observed deaths (Obs) 609, expected deaths (Exp) 516.7, SMR 118, 90\% confidence interval $(90 \% \mathrm{CI}) 110-127)$. As expected in occupational cohort studies, mortality was lower during the first 15 years after entry into the cohort (Obs 69, Exp 71.3, SMR 97, 90\% CI 78-118) than during the remaining period (Obs 540, Exp 445.5, SMR 121, 90\% CI 113-130). To avoid this healthy worker effect bias the rest of the analyses has taken into account a latency of 15 years.

The 1901-1990 mortality from all causes was significantly increased among butchers (Obs 330,
Exp $270 \cdot 3$ SMR $122,90 \%$ CI 111-134) and among pork butchers (Obs 210, Exp 175.3, SMR $120,90 \%$ CI 107-134). Table 2 shows mortality since 1942 for selected malignant and non-malignant causes and incidence of cancer since 1970 for selected sites (table 3). Butchers and pork butchers were at significant excess risk for colorectal cancer, cancer of the prostate, and all malignant neoplasms. The risk of lung cancer was significantly increased among pork butchers (SMR 176, SIR 231) but not among butchers (SMR 92, SIR 113); the difference between the SMRs from lung cancer was significant $(p<0.05)$ and the difference between the SIRs was of borderline significance $(p=0 \cdot 06)$. There were also significant increases in mortality from cancer of the larynx among butchers and in incidence of cancer of the liver among pork butchers.

For the non-malignant causes of death (table 2) there were limited and non-significant differences between butchers and pork butchers. Mortality of all men was significantly increased for circulatory disease, ischaemic heart disease, violent death, motor vehicle accidents, and cirrhosis of the liver.

Further analysis was carried out by calendar period, age, period of birth, and time from first follow up. The incidence of prostatic cancer was highest among the younger butchers (up to 64 years) with five cases $v 0.9$ expected, but the excess diminished significantly with increasing age. Among pork butchers analysis by two birth cohorts indicated that the excess risk for lung cancer was concentrated among those born from 1900 onwards. The mortality from lung cancer among younger pork butchers (Obs 16, Exp 6.6, SMR $242,90 \%$ CI 152-368) was significantly higher $(p<0.05)$ than that among the pork butchers born in 1880-99 (Obs 2, Exp 3.5, SMR 56, 90\% CI 10-175).

Furthermore, there was a cluster of leukaemia among the butchers born in 1880-99 (Obs 5, Exp $0 \cdot 6, p<0.001$ ). Table 4 shows type of leukaemia, years of birth and death, and period of occupational exposure. No latency was taken into account to calculate the observed and expected deaths. The only case, however, with less than 15 years of follow up (born in 1890, see table 4) was traced from age of 19 years: he was employed as a butcher in other Swiss cantons and in Lyon, France, from where he moved to Geneva in 1937. He entered the cohort in 1947 when he started to run his own butchery. No increase in mortality or in incidence from leukaemia was found among the butchers born from 1900 onwards and among the pork butchers.

By contrast with the results of studies from other countries $^{127}$ there was no significantly increased risk for lymphoma (tables 2 and 3), although the number of expected deaths was small. 
Table 2 Mortality 1942-90 from selected causes, allowing for 15 years of latency, among butchers, pork butchers, and all men

\begin{tabular}{|c|c|c|c|c|c|c|c|c|c|}
\hline \multirow[b]{2}{*}{ Cause of death (ICD-8) } & \multicolumn{3}{|c|}{ Butchers } & \multicolumn{3}{|c|}{ Pork butchers } & \multicolumn{3}{|c|}{ All men } \\
\hline & Obs & $S M R$ & $(90 \% C I)$ & Obs & $S M R$ & $(90 \% C I)$ & Obs & $S M R$ & $(90 \% C I)$ \\
\hline All causes $(0-999)$ & 315 & $121^{\star \star \star}$ & $(110-133)$ & 202 & $121^{\star \star}$ & $(107-136)$ & 517 & $121^{\star \star \star}$ & $(113-130)$ \\
\hline All malignant neoplasms (140-209): & 98 & $127^{\star}$ & $(107-150)$ & 59 & $126^{\star}$ & $(100-156)$ & 157 & $127^{\star \star}$ & $(110-144)$ \\
\hline Buccal cavity, pharynx (140-149) & 4 & 108 & $(37-247)$ & 2 & 87 & $(15-274)$ & 6 & 100 & $(44-197)$ \\
\hline Oesophagus (150) & 6 & 154 & $(67-304)$ & 3 & 120 & $(33-310)$ & 9 & 141 & $(73-245)$ \\
\hline Stomach (15i) & 11 & 164 & $(92-272)$ & 4 & 87 & $(30-199)$ & 15 & 133 & $(82-204)$ \\
\hline Colon, rectum $(153,154)$ & 12 & 138 & $(80-223)$ & 13 & $236^{\star \star}$ & $(140-376)$ & 25 & $176^{\star \star}$ & $(122-246)$ \\
\hline Liver (155) & 6 & 200 & $(87-395)$ & 2 & 118 & $(21-370)$ & 8 & 170 & $(85-307)$ \\
\hline Pancreas (157) & 2 & 63 & $(11-196)$ & 4 & 211 & $(72-482)$ & 6 & 118 & $(51-232)$ \\
\hline Larynx (161) & 6 & $300^{\star}$ & $(131-592)$ & 0 & - & $(0-246)$ & 6 & 182 & $(79-359)$ \\
\hline Lung (162) & 17 & 92 & $(59-138)$ & 18 & $176^{\star}$ & $(114-262)$ & 35 & 122 & $(90-162)$ \\
\hline Prostate (185) & 17 & $200^{\star \star}$ & $(127-300)$ & 6 & 111 & $(48-219)$ & 23 & $165^{\star}$ & $(113-234)$ \\
\hline Bladder (188) & 4 & 114 & $(39-262)$ & 1 & 48 & $(2-226)$ & 5 & 89 & $(35-188)$ \\
\hline Kidney (189) & 1 & 56 & $(3-264)$ & 0 & - & $(0-272)$ & 1 & 36 & $(2-169)$ \\
\hline Lymph/haematopoietic (200-209) & 7 & 149 & $(70-280)$ & 2 & 77 & $(14-242)$ & 9 & 122 & $(63-212)$ \\
\hline Hodgkin's disease (201) & 1 & 200 & $(10-949)$ & 1 & 333 & $(17-1581)$ & 2 & 250 & $(44-787)$ \\
\hline \multicolumn{10}{|l|}{ Non-Hodgkin's lymphoma } \\
\hline$(200,202)$ & 2 & 200 & $(36-630)$ & 0 & - & $(0-599)$ & 2 & 125 & $(22-393)$ \\
\hline Leukaemia (204-207) & 4 & 211 & $(72-482)$ & 1 & 91 & $(5-431)$ & 5 & 167 & $(66-350)$ \\
\hline Circulatory disease $(390-458)$ : & 120 & $122^{\star}$ & $(104-142)$ & 74 & 116 & $(94-140)$ & 194 & $120^{\star \star}$ & $(106-135)$ \\
\hline Ischaemic heart disease $(410-414)$ & 35 & $148^{\star}$ & $(110-197)$ & 17 & 142 & $(90-212)$ & 52 & $146^{\star \star}$ & $(114-184)$ \\
\hline \multicolumn{10}{|l|}{ Other heart diseases } \\
\hline$(390-398,420-429)$ & 50 & 111 & $(86-140)$ & 38 & 121 & $(91-159)$ & 88 & 115 & $(96-138)$ \\
\hline Cerebrovascular disease $(430-438)$ & 19 & 102 & $(67-149)$ & 15 & 115 & $(71-178)$ & 34 & 108 & $(79-143)$ \\
\hline Violent death (E800-999) & 21 & 145 & $(97-209)$ & 14 & 159 & $(96-249)$ & 35 & $150^{\star}$ & $(111-199)$ \\
\hline Motor vehicle accident (E810-823) & 5 & 161 & $(64-339)$ & 5 & $263^{\star}$ & $(104-553)$ & 10 & $204^{\star}$ & $(111-346)$ \\
\hline \multicolumn{10}{|l|}{ Other accidents and poisonings } \\
\hline$(\mathrm{E} 800-807,825-949)$ & 9 & 148 & $(77-257)$ & 4 & 105 & $(36-241)$ & 13 & 133 & $(78-211)$ \\
\hline Suicide (E950-959) & 6 & 118 & $(51-232)$ & 4 & 133 & $(46-305)$ & 10 & 125 & $(68-212)$ \\
\hline \multicolumn{10}{|l|}{ All other causes: } \\
\hline$(0-136,210-389,460-796)$ & 72 & 104 & $(84-126)$ & 44 & 92 & $(71-119)$ & 116 & 99 & $(85-116)$ \\
\hline $\begin{array}{l}\text { Chronic bronchitis, emphysema } \\
(491,492)\end{array}$ & 5 & 96 & $(38-202)$ & 3 & 97 & $(26-250)$ & 8 & 96 & \\
\hline Cirrhosis of liver (571) & 14 & $177^{\star}$ & $(107-227)$ & 7 & 143 & $(67-268)$ & 21 & $164^{\star}$ & $(110-236)$ \\
\hline Unknown cause & 4 & & & 11 & & & 15 & & \\
\hline
\end{tabular}

${ }^{\star} \mathrm{p}<0.05 ;{ }^{\star \star} \mathrm{p}<0.01 ;{ }^{\star \star \star} \mathrm{p}<0.001$.

WIVES

Among all wives the 1901 to 1990 mortality from all causes was similar to that expected from Geneva rates (Obs 450, Exp 449.0, SMR 100, 90\% CI, 93-108). There was no significant excess risk for any cancer site (table 5). Incidence of cancer of the cervix uteri was increased, but not significantly. Within the two subcohorts there were significant increases in mortality from non-melanoma skin tumours among butchers' wives (Obs 2, Exp 0.3, $p<0.05)$, and in incidence of cancer of the liver among pork butchers' wives (Obs 2, Exp 0.2 $\mathrm{p}<0.05)$.

Analysis by birth cohort showed an increase in mortality of borderline significance from cancer of the cervix uteri among the butchers' wives born in

Table 3 Incidence of cancer 1970-89 from selected sites, allowing for 15 years of latency, among butchers, pork butchers and all men

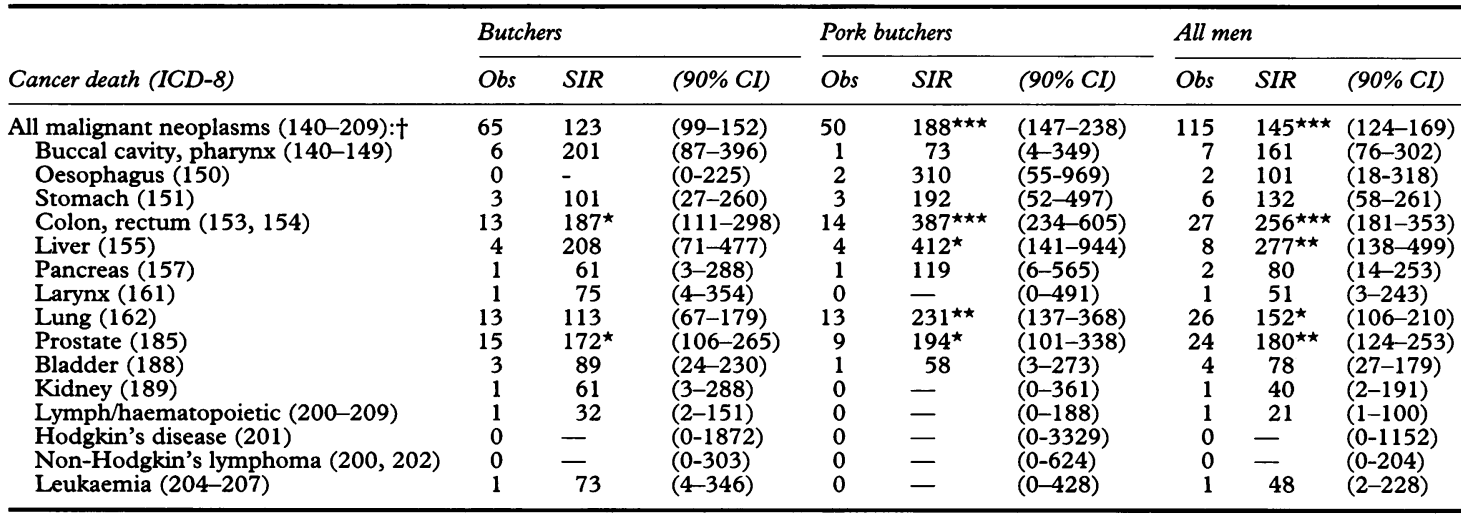

${ }^{\star} \mathrm{p}<0.05 ;{ }^{\star \star} \mathrm{p}<0.01 ;{ }^{\star \star \star} \mathrm{p}<0.001$.

†Excluding non-melanoma skin tumours (173) and in situ cancers. 
Table 4 Deaths from leukaemia among the butchers born in 1880-99

\begin{tabular}{|c|c|c|c|c|c|}
\hline \multirow[b]{2}{*}{ Birth (y) } & \multicolumn{2}{|l|}{ Death } & \multirow{2}{*}{$\begin{array}{l}\text { Entry into the } \\
\text { cohort }\end{array}$} & \multirow{2}{*}{$\begin{array}{l}\text { Traced as employee or } \\
\text { self employed butcher }\end{array}$} & \multirow[b]{2}{*}{ Type of leukaemia } \\
\hline & $(y)$ & Age & & & \\
\hline $\begin{array}{l}1890 \\
1892^{\star} \\
1897 \\
1887 \\
1888\end{array}$ & $\begin{array}{l}1948 \\
1956 \\
1959 \\
1966 \\
1970\end{array}$ & $\begin{array}{l}57 \\
64 \\
61 \\
79 \\
82\end{array}$ & $\begin{array}{l}1947 \\
1922 \\
1929 \\
1920 \\
1922\end{array}$ & $\begin{array}{l}1909-1948 \\
1922 \dagger-1956 \\
1927 \ddagger-1935 \\
1916 \dagger-1958 \\
1920 \dagger-1961\end{array}$ & $\begin{array}{l}\text { Erythroleukaemia } \\
\text { Lymphocytic unspecified } \\
\text { Acute myeloid } \\
\text { Acute myeloid } \\
\text { Chronic lymphocytic }\end{array}$ \\
\hline
\end{tabular}

*Butcher of horse meat.

†Coming to Geneva from other Swiss cantons or from France, probably always butcher.

$\ddagger$ A cook before and after the period of self employed butcher.

Table 5 Cancer mortality 1942-90 and cancer incidence 1970-1989 for selected sites among all wives

\begin{tabular}{|c|c|c|c|c|c|c|c|c|}
\hline \multirow[b]{2}{*}{ Site (ICD-8) } & \multicolumn{4}{|c|}{ Death 1942-90 } & \multicolumn{4}{|c|}{ Cases of cancer 1970-1989* } \\
\hline & Obs & $\operatorname{Exp}$ & $S M R$ & $(90 \% C I)$ & Obs & $\operatorname{Exp}$ & SIR & $(90 \% C I)$ \\
\hline All malignant neoplasms (140-209): & 89 & $105 \cdot 1$ & 85 & $(70-101)$ & 87 & $78 \cdot 1$ & 111 & $(93-133)$ \\
\hline Buccal cavity, pharynx (140-149) & 0 & 1.6 & - & $(0-187)$ & 0 & $1 \cdot 4$ & - & $(0-214)$ \\
\hline Oesophagus (150) & 3 & $1 \cdot 3$ & 231 & $(63-596)$ & 1 & 0.5 & 200 & $(10-949)$ \\
\hline Stomach $(151)$ & 7 & $9 \cdot 4$ & 74 & $(35-140)$ & 5 & 3.9 & 128 & $(51-270)$ \\
\hline Colon, rectum $(153,154)$ & 10 & $14 \cdot 6$ & 68 & $(37-116)$ & 12 & $11 \cdot 7$ & 103 & $(59-166)$ \\
\hline Liver (155) & 2 & $1 \cdot 7$ & 118 & $(21-370)$ & 2 & 0.7 & 286 & $(51-899)$ \\
\hline Gallbladder (156) & 3 & $2 \cdot 7$ & 111 & $(30-287)$ & 2 & 1.5 & 133 & $(24-420)$ \\
\hline Pancreas (157) & 1 & $5 \cdot 0$ & 20 & $(1-95)$ & 2 & $2 \cdot 8$ & 71 & $(13-225)$ \\
\hline Larynx (161) & 0 & $0 \cdot 2$ & - & $(0-1498)$ & 0 & $0 \cdot 3$ & - & $(0-999)$ \\
\hline Lung (162) & 3 & $5 \cdot 7$ & 53 & $(14-136)$ & 3 & $4 \cdot 0$ & 75 & $(20-194)$ \\
\hline Breast (174) & 22 & $23 \cdot 1$ & 95 & $(64-136)$ & 27 & $22 \cdot 7$ & 119 & $(84-164)$ \\
\hline Uterus all parts $(180-182)$ : & 12 & $8 \cdot \overline{4}$ & 143 & $(82-231)$ & 10 & $8 \cdot 3$ & 120 & $(65-204)$ \\
\hline Cervix $(180) \dagger$ & 4 & $3 \cdot 0$ & 133 & $(46-305)$ & 5 & $2 \cdot 6$ & 192 & $(76-404)$ \\
\hline Corpus $(182) \dagger$ & 2 & $2 \cdot 0$ & 100 & $(18-315)$ & 5 & $5 \cdot 5$ & 91 & $(36-191)$ \\
\hline Ovary (183) & 6 & $6 \cdot 5$ & 92 & $(40-182)$ & 3 & $3 \cdot 8$ & 79 & $(22-204)$ \\
\hline Bladder (188) & 1 & $1 \cdot 8$ & 56 & $(3-264)$ & 1 & $1 \cdot 7$ & 59 & $(3-279)$ \\
\hline Kidney (189) & 1 & $1 \cdot 7$ & 59 & $(3-279)$ & 3 & $1 \cdot 6$ & 188 & $(51-485)$ \\
\hline Brain (191) & 3 & $1 \cdot 1$ & 273 & $(74-705)$ & 1 & 0.9 & 111 & $(6-527)$ \\
\hline Lymph/haematopoietic (200-209): & 9 & $7 \cdot 8$ & 115 & $(60-201)$ & 8 & $5 \cdot 1$ & 157 & $(78-283)$ \\
\hline Hodgkin's disease (201) & 0 & 0.9 & - & $(0-333)$ & 0 & 0.2 & - & $(0-1498)$ \\
\hline Non-Hodgkin's lymphoma $(200,202)$ & 1 & 1.5 & 67 & $(3-316)$ & 4 & $1 \cdot 6$ & 250 & $(85-572)$ \\
\hline Leukaemia $(204-207)$ & 5 & $3 \cdot 2$ & 156 & $(62-329)$ & 3 & $2 \cdot 2$ & 136 & $(37-352)$ \\
\hline Others and unknown & 6 & $12 \cdot \overline{5}$ & 48 & $(21-95)$ & 7 & $7 \cdot 2$ & 97 & $(46-183)$ \\
\hline
\end{tabular}

*Excluding non-melanoma skin tumours (173) and in situ cancers.

tMortality since 1951 for cervix uteri and since 1969 for corpus uteri.

1900 or later (Obs 4, Exp 1.4, p = 0.05), and an almost similar increase in incidence (Obs 4, Exp 1.6). There was also a significant excess of deaths from cancer of the uterus (all parts) among pork butchers' wives born in 1880-99 (Obs 5, Exp 1.5, $p<0.05)$. From these deaths, two were listed on the death certificates as cancer of the cervix uteri, but they occurred during the period 1942-50 before the the introduction, in 1951, of cervical cancer as a separated entity in the Swiss classification of the causes of death.

No significant increased risk was found for the non-malignant causes of death (not in table) among all women and among butchers' or pork butchers' wives. Mortality from cirrhosis of the liver among pork butchers' wives was similar to that expected (Obs 1, Exp 1.9).

\section{Discussion}

CANCER OF THE LUNG

An increased risk of lung cancer in butchers was reported in analyses of occupational mortality data from Holland (period 1931-35), ${ }^{16}$ England and Wales $\left(1959-63,{ }^{17} 1966-72,{ }^{18}\right.$ and $\left.1979-83^{19}\right)$, Scotland (1959-63 and 1969-73), ${ }^{20}$ Denmark $(1970-80),{ }^{21}$ and the state of Illinois (1979-84). ${ }^{22}$ The results from Washington State, however, $(1950-79)^{23}$ were negative and a later analysis of the Denmark Cancer Registry data $(1970-79)^{24}$ did not confirm the mortality finding. Data on smoking habits were available from England and Wales where they indicated that butchers were slightly less likely to be current smokers than all men. ${ }^{19}$

In Sweden the 1961-73 incidence of lung cancer was significantly increased among all men regis- 
tered as a butcher or slaughterhouse worker in the census of $1960 .^{18}$ The increase was higher among those in slaughterhouses than among the others. A case control study based on the same population failed to find any work task associated with lung cancer. ${ }^{6}$ Tobacco smoking habits contributed at least a part of the excess risk.

Two cohort studies among butchers and other meat workers have been reported. Among the 28901 members of a meatcutters' union in Baltimore, United States, a significant increase in mortality from lung cancer was found among male workers in abattoirs and in meat packing plants and among female workers in chicken slaughtering plants, meat packing plants, and retail food stores. ${ }^{1-3} \mathrm{~A}$ nested case-control analysis found that the risk excess was not explained by smoking habits and was highest among men working in stockyards or in killing and dressing areas of slaughterhouses.

The second cohort study was carried out among 1610 meat workers employed at three British companies, two of which were processing pork only. ${ }^{5}$ Mortality from lung cancer was significantly increased among those who were regularly exposed to meat from freshly slaughtered animals, although tobacco smoking was not controlled.

Also there were two smoking adjusted case control studies in the United Sates ${ }^{25}{ }^{26}$ that showed no association of lung cancer with butchers, whereas two unadjusted studies in New Zealand ${ }^{27}$ and in Germany ${ }^{28}$ did show such an association.

Among Geneva pork butchers, mortality from and incidence of lung cancer were significantly higher than expected from the whole Geneva population rates, whereas no such increases were found among Geneva butchers. The difference in mortality from lung cancer between butchers and pork butchers was significant but only of borderline significance for incidence of lung cancer.

It is unlikely that different smoking habits could explain why the risk of lung cancer was higher among pork butchers than among butchers. Similar lifestyles would be expected in these occupations because they are much the same. This seems supported by the rates of current smokers in the study on dietary habits undertaken in 1989 although the number of men, especially of pork butchers, was small.

The high risk of lung cancer among Geneva pork butchers might be related to their exposure to the fumes from meat smoking. These fumes are rich in PAHs, which are strongly suspected, from experimental studies on tobacco smoke, to play an important part in the induction of lung cancer in tobacco smokers. ${ }^{29}$ Probably nearly all pork butchers practised meat smoking from the start of their career whereas very few butchers practised it, and only after 1950 .
Exposure to nitrosamines from meat consumption, and possibly by inhalation from curing mixtures, was probably higher among pork butchers than among butchers. Some nitrosamines produce respiratory tract tumours in animals and are suspected of inducing lung cancer in humans. ${ }^{29}$ Although we do not know if these nitrosamines were actually consumed or inhaled by Geneva pork butchers, their possible role in the excess of lung cancer found in this occupation should be considered.

To our knowledge no data on risk of cancer among self employed pork butchers have been published. The SMR from lung cancer, however, was 200 , based on 10 deaths, among meat and fish curers and smokers in the report of the 1951 census on occupational mortality in England and Wales. ${ }^{17}$ This result seems to support the hypothesis that the increased risk of lung cancer among Geneva pork butchers might be related to a hazard during the smoking and curing of pork.

In the American and the British cohort studies the highest risk of lung cancer was found among workers in contact with living or freshly slaughtered animals. ${ }^{45}$ Our results support this association as far as pork is concerned. Geneva pork butchers slaughtered pigs until 1949 and afterwards were still exposed to warm meat until 1975 . In the studies mentioned it was suggested that infection by oncogenic viruses, transmitted through contact with warm meat, might account for the excess deaths from lung cancer.

Whatever the possible occupational factor(s) that could have played a part in the excess deaths from lung cancer of pork butchers, it remains to be explained why this excess was concentrated among those born from 1900 onwards and was absent among those born in 1880-99. We suggest a synergistic effect of occupational factor(s) with cigarette smoking. Available data from Switzerland indicate that the average number of cigarettes per adult rose dramatically from 174 in 1924 to 3378 in $1972 .{ }^{30}$ There is little doubt therefore, that men born in 1880-99 smoked less than those born in the subsequent decades.

\section{PROSTATIC AND COLORECTAL CANCERS}

There is evidence from international comparisons, and from case control and cohort studies, of a strong correlation of cancer of the prostate with colorectal cancer and with consumption of animal fat. ${ }^{14}$ An association of colorectal cancer with consumption of animal protein was also reported, although more recent epidemiological studies have given contrasting results. ${ }^{14}$ The increased risk for these cancers among Geneva butchers and pork butchers might be related to dietary factors, 
especially to their presumably high intake of animal fat and protein, which seems supported by the results of the contemporary dietary study.

As far as cancer of the prostate is concerned, an increased mortality was found among butchers from England and Wales for the years $1970-72^{31}$ and $1979-83^{19}$ and it has been suggested that this increase could be related to the use of androgens as growth promoters in cattle during that period. ${ }^{8}$ It was calculated, however, that if a butcher ate $500 \mathrm{~g}$ steak every day from treated cattle, he would ingest an amount of androgens corresponding to $0.01 \%$ of his daily endogenous production. ${ }^{32}$ Moreover, the excess in mortality from cancer of the prostate among Geneva butchers was already obvious before the use of anabolic agents (Obs 5, Exp 2.2, for the period 1942-69).

Tables 2 and 3 show that the risk of colorectal cancer was higher among pork butchers than among butchers. The difference, however, was not significant for mortality and was only of borderline significance for incidence $(p=0.06)$. We suggest that the higher risk for colorectal cancer among pork butchers could possibly be related to their likely higher intake of nitrosamines, discussed previously.

Our finding of an association of colorectal cancer with butchers and pork butchers is supported by the results of a mortality study among a $10 \%$ sample of the Canadian labour force (1965-73) that showed a significant increase, based on five deaths, in cancer of the rectum and rectosigmoid junction among butchers and meat cutters. ${ }^{33}$

\section{LEUKAEMIA AND LYMPHOMA}

The highly significant excess of deaths from leukaemia among the butchers born in 1880-99 is striking. Older butchers slaughtered cattle and sheep until 1949. Because of their intimate contact with the blood of cattle, older butchers were potentially exposed to the bovine leukaemia virus (BLV). ${ }^{1734}$ The prevalence of BLV infection in Geneva herds during the first decades of this century is, however, unknown. The serological tests carried out during the past two decades by the Geneva veterinary authorities on cattle blood and milk indicated a rate of infected animals of less than $1 \%$. Also there is no serological and epidemiological evidence that BLV might account for the occurence of cases of human leukaemia. ${ }^{34} 35$ Moreover, Geneva butchers could not be exposed to the avian leukosis virus (AVL) that causes leukaemia in chickens ${ }^{134}$ because poultry were slaughtered and cleaned by farmers.

The increased risk for leukaemia among Geneva butchers was not accountable for by only one cell type (table 4). This is not entirely consistent with the finding of a significant association, based on nine cases, of slaughterouse workers with acute myeloid leukaemia only in a case-control study from New Zealand. ${ }^{7}$ Nevertheless the viral aetiology of leukaemia has been shown in several animal species and it is strongly suspected that unknown infectious agents play an important part in the induction of human leukaemia. ${ }^{35}$

On the other hand, we found no significantly higher risks for Hodgkin's disease and nonHodgkin's lymphoma such as those previously reported among meat workers. ${ }^{127}$ The numbers of expected deaths and cancer cases in our study were small.

\section{OTHER CAUSES OF DEATH}

Excessive consumption of animal fat is a risk factor for ischaemic heart disease and probably played a part in the significant mortality increase from this disease among all men. The significant mortality excess from liver cirrhosis among all men strongly suggests that butchers and pork butchers were at higher risk for alcohol abuse than the average male population of Geneva. The significant increases in incidence of cancer of the liver and in mortality from violent death and from motor vehicle accidents among all men, as well as the significant excess mortality from cancer of the larynx among butchers, are consistent with an increased consumption of alcohol. Moreover, if all alcohol related cancers are taken together (buccal cavity, pharynx, oesophagus, liver, and larynx) there were significant excess risks among all men for mortality (Obs 29, Exp 20.4, p $<0.05$ ) and for incidence (Obs 18, Exp 11.2, p < 0.05).

\section{BUTCHERS' AND PORK BUTCHERS' WIVES}

The significant excess in mortality from liver cancer among pork butchers' wives, based on only two observed deaths, is likely to be explained by chance. There is no suggestion of an increased consumption of alcohol considering the lack of any excess risk for liver cirrhosis, although the number of expected deaths was small.

Among butchers' and pork butchers' wives the risk of colorectal cancer and the risk of breast cancer were not significantly increased. An association of these cancers with the consumption of animal fat has been found in a number of studies. ${ }^{14}$ Therefore, there is little suggestion that the unhealthy dietary habits strongly suspected among butchers and pork butchers were shared by their wives.

The increased risks for cancer of the cervix uteri among butchers' wives born in 1900 or later and for cancer of the uterus, possibly also attributable to cervical cancer, among the older pork butchers' wives are consistent with preceding reports. As 
early as 1909 an excess of cancer of the uterus among butchers' wives was noted in Vienna. ${ }^{36}$ Furthermore an association of cervical cancer with butchers' wives was found in the analyses of national mortality data from Holland for 1931-35 16 and from England and Wales for $1970-72 .{ }^{37} \mathrm{~A}$ viral infection transmitted by their husbands was suggested to explain this association. ${ }^{37}$

In conclusion our results indicating excess risks for cancers of the lung, prostate, and intestine, and for leukaemia are consistent with those of other studies among meat workers, although we did not find a significant excess of lymphatic tumours, possibly due to small numbers. The mortality pattern of meat workers is not very different from that of farmers who experience high risks especially for Hodgkin's disease, multiple myeloma, leukaemia, and cancers of the prostate and stomach. ${ }^{38}$ This similarity suggests a risk related to contact with animals, possibly oncogenic viruses, especially accounting for the excesses of lymphatic and haematopoietic tumours.

The separation of the occupations of butcher and pork butcher in Geneva has allowed us to point to a risk of leukaemia associated with the slaughtering of cattle and sheep but not pigs, and to a risk of lung cancer associated only with pork butchers.

We are grateful to Mr PM Sweetnam, statistician, from the MRC Epidemiology Unit (South Wales), Penarth and Dr B Hassene from the Geneva veterinary authorities for help and advice. We also thank Dr E S Johnson (Research Triangle Park NC), Professor M A Cooke (Birmingham), Professor $\mathrm{H}$ Savolainen (Lausanne), Professor G Arlettaz (Geneva), and Mr C W Nuttall (Geneva). We have benefited from the technical assistance of $\mathrm{Dr} T$ Spuhler from the "Office fédéral de la statistique" and Mrs C Santschi from the "Archives d'Etat de Genève".

Requests for reprints to: Dr E Gubéran, médecin inspecteur du travail, 23 rue Ferdinand-Holder, CH-1207 Geneva, Switzerland.

1 Johnson ES, Fischman HR, Matanoski GM, Diamond E. Cancer mortality among white males in the meat industry. f Occup Med 1986;28:23-32.

2 Johnson ES, Fischman HR, Matanoski GM, Diamond E. Occurence of cancer in women in the meat industry. $B r \dot{F}$ Ind Med 1986;43:597-604.

3 Johnson ES. Mortality among nonwhite men in the meat industry. F Occup Med 1989;31:270-2.

4 Johnson ES. Nested case-control study of lung cancer in the meat industry. F Natl Cancer Inst 1991;83:1337-9.

5 Coggon D, Pannett B, Pippard EC, Winter PD. Lung cancer in the meat industry $\mathrm{Br} \mathcal{F}$ Ind Med 1989;46:188-91.

6 Gustavsson P, Fellenius E, Hogstedt C. Possible causes of increased lung cancer incidence among butchers and slaughterhouse workers. Scand $f$ Work Environ Health 1987;13:518-23.
7 Pearce N, Smith AH, Reif JS. Increased risks of soft tissue sarcoma, malignant lymphoma, and acute myeloid leukemia in abattoir workers. Am $\mathcal{F}$ Ind Med 1988;14:63-72.

8 James WH. Prostatic cancer, butchers, and androgens. Lancet 1987;i:217.

9 Gubéran $E$, Usel $M$. Unusual mortality pattern among short term workers in the perfumery industry in Geneva. $B r f$ Ind Med 1987;44:595-601.

10 Breslow NE, Day NE. Statistical methods in cancer research. Vol II. The design and analysis of cohort studies. Lyon: International Agency for Research on Cancer, 1987:91-103.

11 Nordholm L, Espensen IM, Jensen HS, Holst E. Polycyclic aromatic hydrocarbons in smokehouses. Scand $f$ Work Environ Health 1986;12:614-8.

12 Sen NP, Miles WF, Donaldson B, Panalaks T, Iyengar JR. Formation of nitrosamines in a meat curing mixture. Nature 1973;245:104-5.

13 Craddock VM. Nitrosamines, food and cancer: assessment in Lyon. Food Chem Toxicol 1990;28:63-5.

14 Tomatis L, Aitio A, Day NE, et al. Cancer: causes, occurence and control. Lyon: International Agency for Research on Cancer, 1990:203-14,298-300. (Sci Publ. No 100.)

15 Raymond L, Mabiala I, Fioretta G, Usel M. L'alimentation des bouchers est-elle un déterminant de leur risque augmenté pour certains cancers? (in preparation)

16 Versluys JJ. Cancer and occupation in the Netherlands. $\mathrm{Br} F$ Cancer 1949;3:171-85.

17 Griffith GW. Lung cancer in butchers. Lancet 1982;i:399.

18 Fox AJ, Lynge E, Malker H. Lung cancer in butchers. Lancet 1982;i:165-6.

19 Registrar General. Occupational mortality 1979-80, 1982-83. London: HMSO, 1986 (Series DS no 6.)

20 Editor. Cancer and work: a way forward. Lancet 1983; i:511-2.

21 Lynge E., Andersen O, Kristensen TS. Lung cancer in Danish butchers. Lancet 1983;i:527-8.

22 Mallin K, Rubin M, Joo E. Occupational cancer mortality in Illinois white and black males, 1979-1984, for seven cancer sites. Am F Ind Med 1989;15:699-717.

23 Milham S. Lung cancer in butchers. Lancet 1982;i:690.

24 Olsen JH, Jensen OM. Occupation and risk of cancer in Denmark. Scand $\mathcal{f}$ Work Environ Health 1987; (suppl 1): 1-91.

25 Vena JE, Byers T, Swanson M, Cookfair D. Lung cancer in butchers? Lancet 1982;ii:713.

26 Schoenberg JB, Stemhagen A, Mason TJ, Patterson J, Bill J, Altman R. Occupation and lung cancer risk among New Jersey white males. $\mathcal{F}$ Natl Cancer Inst 1987;79:13-21.

27 Reif JS, Pearce NE, Fraser J. Cancer risks in New Zealand meat workers. Scand $\mathcal{f}$ Work Environ Health 1989;15:24-9.

28 Doerken H, Rehpenning W. Lung cancer in butchers. Lancet $1982 ; \mathbf{i}: 561$.

29 Hecht SS, Hoffmann D. N-Nitroso compounds and tobaccoinduced cancers in man. In: O'Neill IK, Chen J, Bartsch H, eds. Relevance to human cancer of n-nitroso compounds, tobacco and mycotoxins. Lyon: International Agency for Research on Cancer, 1991:54-61. (Sci publ No 125.)

30 Gubéran E. Tendances de la mortalité en Suisse. 3. Tumeurs: 1921-1978. Schweiz Med Wochenschr 1980;(suppl 11):1-18.

31 Registrar General. Occupational mortality 1970-72. London: HMSO, 1978. Series DS No 1.

32 Heitzman RJ. Butchers and prostate cancer. Lancet 1987; i:453.

33 Howe GR, Lindsay JP. A follow-up study of a ten-percent sample of the Canadian Labor Force. I. Cancer mortality in males, 1965-73. F Natl Cancer Inst 1983;70:37-44.

34 Blair A, Malker H, Cantor KP, Burmeister L, Wiklund K. Cancer among farmers: A review. Scand $\mathcal{f}$ Work Environ Health 1985;11:397-407.

35 Heath CW. The leukemias. In: Schottenfel D, Fraumeni JF. Cancer epidemiology and prevention. Philadelphia: WB Saunders, 1982:728-38.

36 Theilhaber A. Zur Lehre von der Entstehung der Uterustumoren. Muncherer Medizinische Wochenschrift 1909; 61:1972-3.

37 Robinson J. Cervical cancer: occupational risks. Lancet 1983;ii: 1496-7.

38 Blair A, Hoar Zahm S, Pearce NE, Heineman EF, Fraumeni $\mathrm{JF}$. Clues to cancer etiology from studies of farmers. Scand $\mathcal{F}$ Work Environ Health 1992;18:209-15.

Accepted 11 January 1993 